\title{
Letter
}

\section{The effect of thermal annealing on the properties of thin alumina films prepared by low pressure metal-organic chemical vapour deposition}

\author{
V.A.C. Haanappel, D. v.d. Vendel, H.D. van Corbach, T. Fransen, P.J. Gellings \\ University of Twente, Department of Chemical Technology, P.O. Box 217, 7500 AE Enschede, Netherlands
}

Received 15 September 1994; accepted 11 October 1994

\begin{abstract}
Thin amorphous alumina films were prepared on stainless steel, type AISI 304, by low pressure metal-organic chemical vapour deposition. The effect of thermal annealing in nitrogen (for 2,4 and $17 \mathrm{~h}$ at 600,700 and $800{ }^{\circ} \mathrm{C}$ ) on the film properties, including the protection of the underlying substrate against high temperature corrosion and the chemical composition of the film, were investigated.

Corrosion experiments performed at $450{ }^{\circ} \mathrm{C}$ in a hydrogen sulphide-containing gas, showed that the thermal annealing process had a detrimental effect on the protective properties of the alumina films. From FTIR and Auger measurements, it was found that the amorphous alumina, containing boehmite, converted to $\gamma$-alumina during the annealing process.
\end{abstract}

Keywords: Aluminium oxide; Chemical vapour deposition; Coatings; Fourier transform infrared spectroscopy

\section{Introduction}

Thin films of alumina have previously been prepared by metal-organic chemical vapour deposition (MOCVD) [1-8]. One of the advantages of MOCVD over conventional CVD, is the low process temperature which directly leads to a lowering of the energy consumption of the process. The low deposition temperature is also of importance for the deposition of protective overlay coatings on substrates which could easily deteriorate at high temperatures [9]. Today, several metal-organic compounds have been used for the deposition of thin alumina films, such as, aluminiumacetyl-acetonate [10-14], aluminium-tri-ethoxide [7], aluminium-tri-iso-propoxide $[2-4,15]$, aluminium-2ethyl-hexanoate [16], and aluminium-tri-sec-butoxide [17-20]. Atmospheric as well as low pressure MOCVD has been used as a process for the deposition of thin alumina films. These films offer, in principle, great potential because of the large number of possible applications, such as insulating layers, optical filters, wear resistant coatings and corrosion protective coatings.
In this letter the effect of thermal annealing on the physical and chemical properties of thin alumina films, deposited on stainless steel AISI 304 by low pressure metal-organic chemical vapour deposition, is described. Sulphidation experiments were used to investigate the porosity and the film. Auger electron spectroscopy (AES) and Fourier transform infrared (FTIR) spectroscopy were used to characterize the oxide film.

\section{Experimental}

Thin alumina coatings were produced by decomposition of aluminium-tri-sec-butoxide (ATSB, Janssen Chimica) at reduced pressure $(0.167 \mathrm{kPa}$ (1.25 Torr)) A stream of nitrogen gas was passed through the ATSB precursor. This saturated gas was diluted with pure nitrogen gas before entering the reactor. The gas line between the ATSB container and the reactor was heated to $150{ }^{\circ} \mathrm{C}$ to prevent condensation of the precursor. A full description of the low pressure MOCVD 
system is given elsewhere [21]. Standard conditions for the production of an alumina film with a thickness of $0.5 \mu \mathrm{m}$ were: deposition temperature, $280{ }^{\circ} \mathrm{C}$; partial pressure of ATSB, $3.7 \times 10^{-4} \mathrm{kPa}$ (ATSB saturation temperature, $134 \mathrm{C}$ ); reactor pressure, $0.17 \mathrm{kPa}$; and gas flow, $11 \mathrm{~min}^{-1}$.

Depositions were performed on stainless steel, type AISI $304(18 \% \mathrm{Cr}, 8 \% \mathrm{Ni}, 0.08 \% \mathrm{C}, 1 \% \mathrm{Si}, 2 \% \mathrm{Mn}$, $71 \% \mathrm{Fe}$ ). The AISI 304 samples (discs with a diameter of $20 \mathrm{~mm}$ and a thickness of $1 \mathrm{~mm}$ ) were ground on $\mathrm{SiC}$ paper to a final size of 4000 grit followed by a polishing treatment with $\mathrm{Al}_{2} \mathrm{O}_{3}(3 \mu \mathrm{m})$ and subsequently cleaned ultrasonically for $30 \mathrm{~min}$ in soap, hexane and ethanol. Finally, the samples were immersed in Streuer's etching fluid $5 \%$ solution of $3 \mathrm{M}$ nitric acid in ethanol) for 15 min, washed with pure ethanol and dried in hot air.

After the deposition process, the ATSB flow was stopped and the samples were exposed to a nitrogen atmoxphere at temperatures ranging from 600 to 800 $\mathrm{C}$, and during 2,4 and $17 \mathrm{~h}$. After finishing the thermal annealing period, the temperature was lowered below $200 \mathrm{C}$ before the samples were removed from the furnace.

Corrosion experiments were performed in order to invest gate the protective capacity, i.e. the porosity, of the films against aggressive gas components such as oxyge 1 and sulphur at high temperatures and were carried out in a closed system at $450{ }^{\circ} \mathrm{C}$ for $70 \mathrm{~h}$ (gas mixture: $1 \% \mathrm{H}_{2} \mathrm{O}, 1 \% \mathrm{H}_{2} \mathrm{~S}, 19 \% \mathrm{H}_{2}$, bal. Ar).

The morphology and the composition of the corroded specimens were investigated by means of optical and scanning electron microscopy (JEOL M $35 \mathrm{CF}$ ), the latter equipped with an EDX analysis system (Kevex Delta, class III).

To characterize the chemical composition and the depth profile, the alumina films were analysed using a Perkir-Llmer PHII 600 scanning Auger multiprobe. Alternate sputtering and Auger analysis were used during in-depth analysis. The functional groups including hydrogen-containing bonds within the films were measured by Fourier transform infrared spectroscopy (FTIR), using a Nicolet 20 SX FTIR apparatus. Due to the non-transparency of the specimens, the spectrometer was equipped with a diffuse reflection cell. The microstructure of the films was investigated by X-ray diffraction (XRD), using a Philips PW 1710 X-ray diffractometer with monochromatic $\mathrm{CuK} \alpha$ radiation.

\section{Results and discussion}

The effect of temperature and exposure time of the post-deposition thermal treatment on the corrosion attack is shown in Fig. 1. From this figure it is clear that the amount of corrosion products increases with increasing annealing temperature and/or time. The best

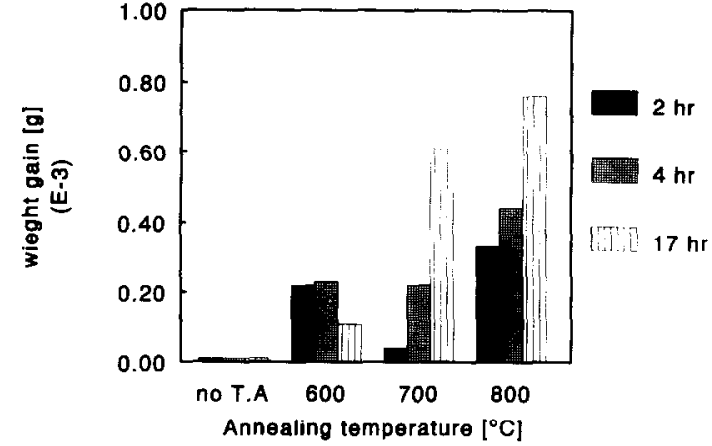

Fig. 1. Bar diagram of the weight gain $g$ of the specimens as a function of the thermal annealing time and temperature.

protection against high temperature corrosion was obtained for the unannealed samples. SEM analysis showed the formation of mainly FeS, corresponding to the thermodynamically most stable phases [22]. Probably, due to the anneal treatment, microcracks or micropores were formed which act as fast diffusion paths for the aggressive gas compounds [19]. The presence of cracks can be attributed to the formation of thermal stress and a lower adhesion strength between the substrate and the oxide film [22].

Fig. 2 shows the FTIR adsorption spectra of the annealed samples at $700 \mathrm{C}$. Two specific absorption bands were found at $900-950 \mathrm{~cm}^{-1}$ and $3000-3700$ $\mathrm{cm}^{-1}$, indicative of the $\mathrm{Al}-\mathrm{O}$ and $\mathrm{O}-\mathrm{H}$ bonds, respectively. This figure shows that the $\mathrm{O}-\mathrm{H}$ absorption band decreases in intensity at a given annealing temperature with increasing annealing time. The absorption band around $900-950 \mathrm{~cm}^{-1}$, increases in intensity. The maximum of this $\mathrm{Al}-\mathrm{O}$ peak changed from $925 \mathrm{~cm}^{-1}$ for the unannealed samples, to $950 \mathrm{~cm}$ ' for samples annealed at $800 \mathrm{C}$, indicative of a lower internal stress in the alumina film [22].

From previous results $[19,20]$, it is assumed that, due to the presence of $\mathrm{OH}$ groups, the as-deposited alumina film consists partly of boehmite $(\mathrm{AlO}(\mathrm{OH}))$. According to Stumpf et al. [23], $\gamma$-alumina was found as the crystalline phase after thermal annealing. If $\mathrm{AlO}(\mathrm{OH})$ were incorporated in the film, it will decompose to alumina and water at high temperatures:

$2 \mathrm{AlO}(\mathrm{OH})-\Delta T-\mathrm{Al}_{2} \mathrm{O}_{3}(1-x) \mathrm{H}_{2} \mathrm{O}+x \mathrm{H}_{2} \mathrm{O}$

The transition of $\mathrm{AlO}(\mathrm{OH})$ to $;$-alumina was also found by Goton [24], Bugosh et al. [25] and Saalfeld [26]. Goton [24] found dehydroxylation of boehmite into $\mathrm{Al}_{2} \mathrm{O}_{3}$ (with 0.1 mole $\mathrm{H}_{2} \mathrm{O}$ per mole of $\mathrm{Al}_{2} \mathrm{O}_{3}$ ). Bugosh et al. [25] and Saalfeld [26] found that heating of $\mathrm{AlO}(\mathrm{OH})$ results subsequently into $y_{-}, 0-$ and $\alpha$-alumina.

The composition and the depth profile of the annealed alumina films were investigated by Auger electron spectroscopy (AES) in combination with ion 


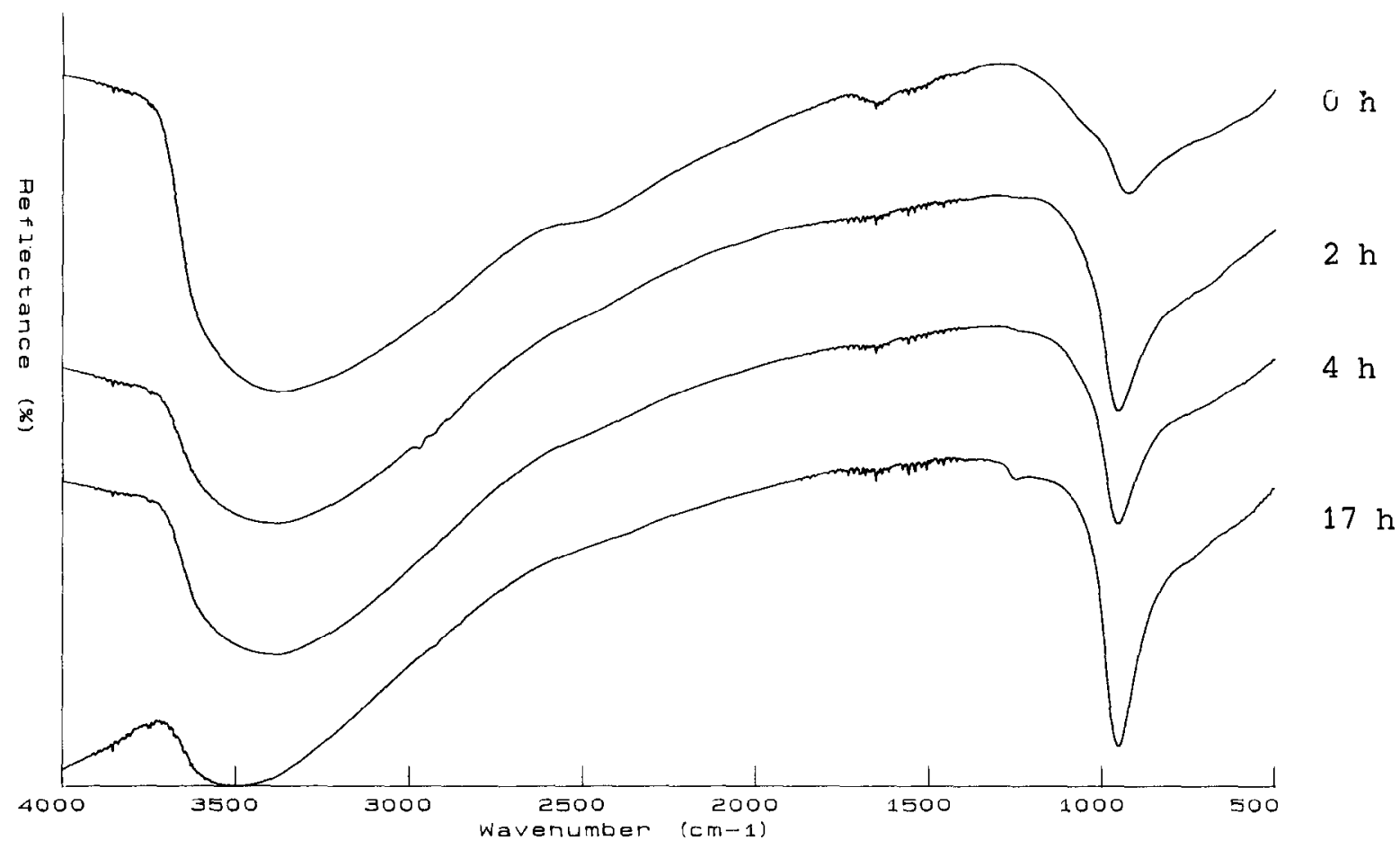

Fig. 2. FTIR reflectance spectra of alumina films annealed at $700 \mathrm{C}$ for $0,2,4$ and $17 \mathrm{~h}$.

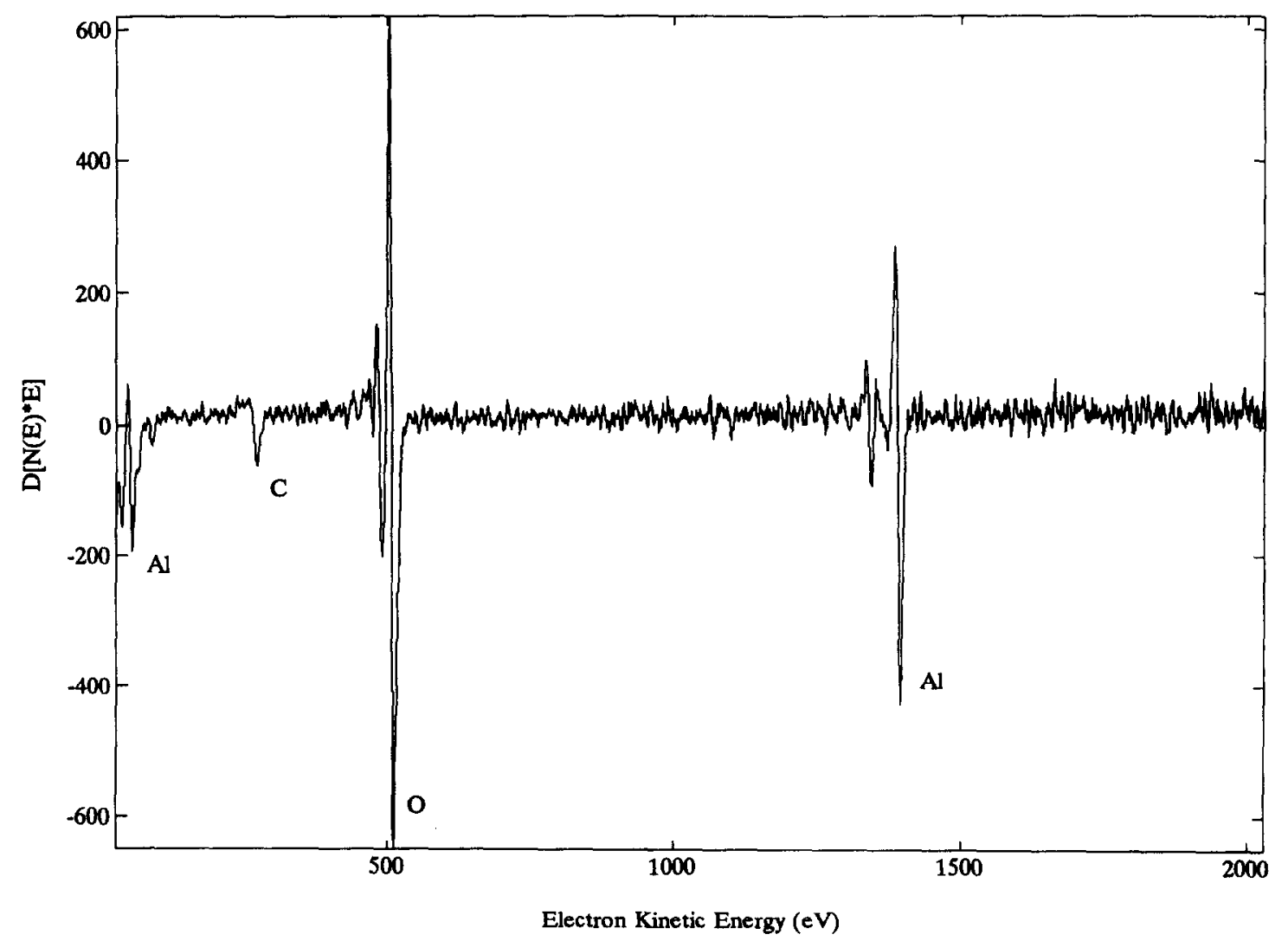

Fig. 3. AES survey scan analysis of the alumina film on AISI 304, after thermal annealing for $17 \mathrm{~h}$ at $800{ }^{\circ} \mathrm{C}$. 


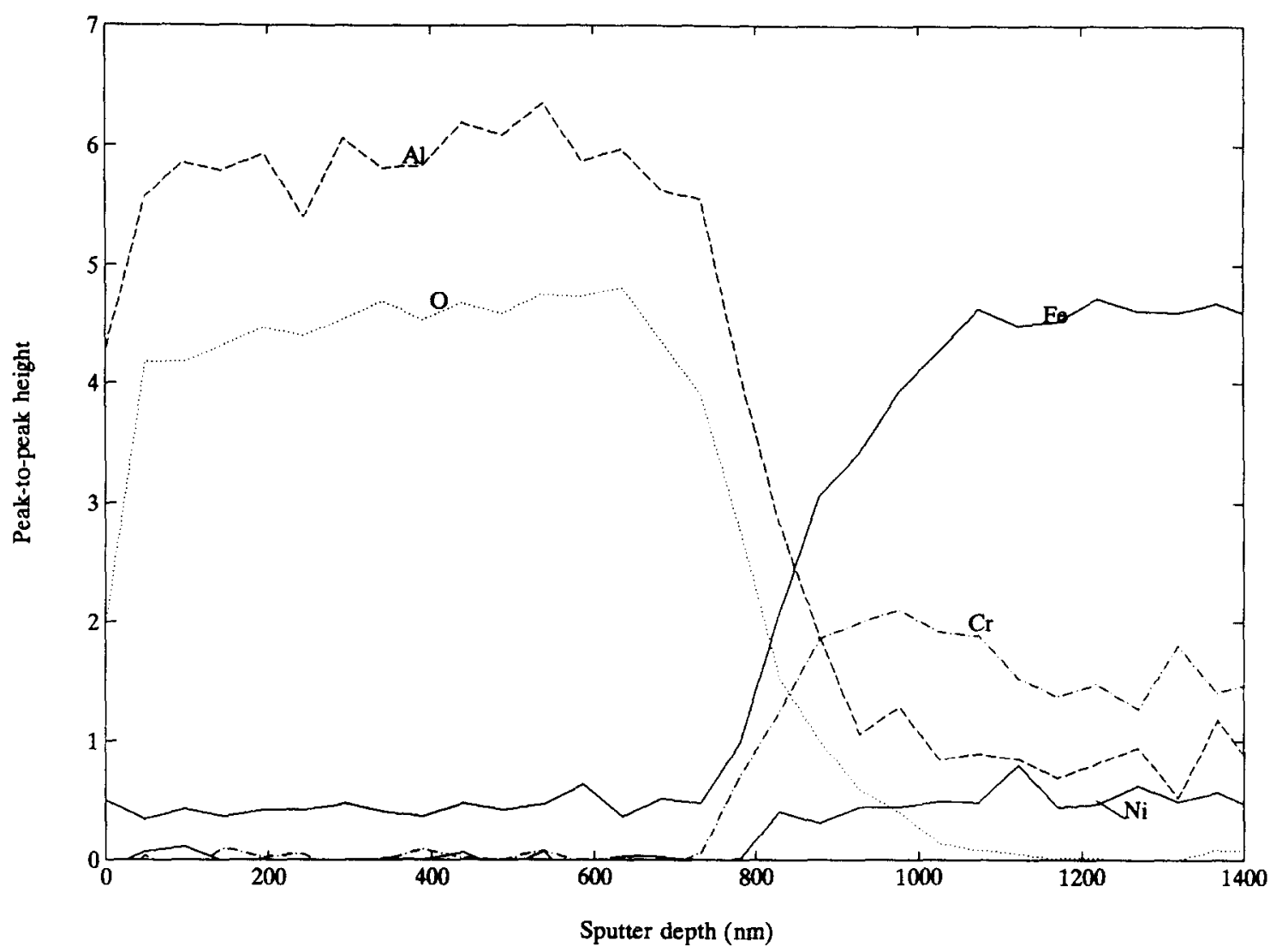

Fig. 4. AES depth profile analysis of the alumina film on AISI 304, after thermal annealing for $17 \mathrm{~h}$ at $800 \mathrm{C}$.

sputtering. From the steady state spectrum (survey scan) it is clear that next to $\mathrm{Al}$ and $\mathrm{O}$ a small amount of carbon was detected, even after annealing for $17 \mathrm{~h}$ at $800^{\circ} \mathrm{C}$ (Fig. 3). After one or more sputtering cycles (one cycle corresponds with one minute sputtering at a rate of $44 \mathrm{~nm} \min ^{-1}$ ) no carbon was found anymore. This migh1 be explained by the adsorption of carbon containing compounds, such as carbon dioxide and hydrocar bons on the outside of the alumina layer. Fig. 4 shows the AES depth profile analysis of the alumina film on AISI 304 after $17 \mathrm{~h}$ at $800{ }^{\circ} \mathrm{C}$. It was found that for the unannealed samples the interface was rather distinct. After longer annealing times and higher annealing temperatures, the interface became less distinct, due to penetration of alloying elements into the alumina film. Also small amounts of sulphur were detected at the interface. Due to the miscibility of chromium and aluminium and the segregation of sulphur at the interface, the adhesion strength significantly decreased resulting in a higher susceptibility to crack formation [24].

XRD patterns did not reveal any transformation from amorphous to crystalline alumina, possibly owing to the slight thickness of the film. Earlier experiments [19] with alumina films deposited at atmospheric pressure showed a conversion from amorphous to $\gamma$-alumina.

\section{Conclusions}

From the corrosion experiments it was observed that the post-deposition thermal treatment did not exert any beneficial effect on the protectiveness of the alumina films against high temperature corrosion. This annealing process resulted in a reduction of the amount of $\mathrm{OH}$ groups in the film, probably attributed to the presence of boehmite. During the annealing period the oxide-alloy interface changes as a result of diffusion of alloying elements to or into the alumina matrix.

\section{Acknowledgments}

This research was supported by the Innovative Research Program on Technical Ceramics (IOP-TK) with financial aid of the Dutch Ministry of Economic Affairs. Thanks are due to L. Vrielink for the FTIR measurements, A.H.J. van den Berg (CMO) for the AES experiments, and J. Boeijsma for the XRD measurements.

\section{References}

[1] T. Maruyama and S. Arai, Appl. Phys. Lett., 60(3) (1992) 322. [2] J.A. Aboaf, J. Electrochem. Soc.: Solid State Sci., 114 (1967) 948. 
[3] M.T. Duffy, J.E. Carnes and D. Richman, Metallurgical Trans., 2 (1971) 667.

[4] C. Dhanavantri, R.N. Karekar and V.J. Rao, Thin Solid Films, 127 (1985) 85.

[5] A.A. Barybin, V.I. Tomilin, V.A. Kempel and E.A. Makhotin, Pribory i Tekhnika Eksperimenta, 3 (1975) 238.

[6] J. Saraie, J. Kwon and Y. Yodogawa, J. Electrochem. Soc., 132 (1985) 890

[7] M. Matsushita and Y. Koga, J. Electrochemical Soc., 115(1968) 69C.

[8] S.S. Yom, W.N. Kang, Y.S. Yoon, J.I. Lee, D.J. Choi, K.Y. Seo, P.H. Hur and F.Y. Kim, Thin Solid Films, 213 (1992) 72.

[9] P.J. Gellings, British Corrosion J., 27(2) (1992) 105.

[10] O.B.A. Ajayi, M.S. Akanni, H.D. Burrow, J.N. Lambi, O. Osasona and B.P. Podor, Thin Solid Films, 138 (1986) 91.

[11] O.B.A. Ajayi, M.S. Akanni, J.N. Lambi, C. Jeynes and J.F. Watts, Thin Solid Films, 185 (1990) 123.

[12] V.M. Koleshko, V.V. Sviridov, V.P. Boldyrev, B.S. Reznikov, I.V. Nekaryukin, K.D. Yashin, N.N. Goroshko and A.A. Kovalevskii, Neorganichoeskie Materialy, 12 (1976) 1780.

[13] V.P. Boldyrev, V.M. Koleshko, B.S. Resnikov, I.V. Nekaryukin, L.D. Buiko and K.D. Yashin, Neorganicheskie Materialy, 12 (1976) 2181

[14] K. Kamata, European Patent Application EP 0055459 Al.

[15] R.W.J. Morssinkhof, The Deposition of Thin Alumina Films on Steels by MOCVD, PhD Thesis, University of Twente, Netherlands, 1991
[16] T. Maruyama and T. Nakai, Appl. Phys. Lett., 58(19) (1991) 2079.

[17] K. Okuyama, Y. Kousaka, N. Tohge, S. Yamamoto, J.J. Wu, R.C. Flagan and J.H. Seinfeld, AIChE J., 32 (1986) 2010.

[18] Y.Y. Baryshnikov, I.L. Zakharov and G.I. Makin, Zhurnal Obshchei Khimii, 60(6) (1990) 1350.

[19] V.A.C. Haanappel, Alumina Films on Metallic Substrates by MOCVD, PhD Thesis, University of Twente, Enschede, Netherlands. 1994.

[20] V.A.C. Haanappel, H.D. van Corbach, T. Fransen and P.J. Gellings, Surface Coatings Technol., 63 (1994) 145.

[21] H.D. van Corbach, V.A.C. Haanappel, T. Fransen and P.J. Gellings, Thin Solid Films, 239 (1994) 31.

[22] V.A.C. Haanappel, H.D. van Corbach, T. Fransen and P.J. Gellings. The effect of thermal annealing on the adherence of $\mathrm{Al}_{2} \mathrm{O}_{3}$ films deposited by low pressure metal-organic chemical vapour deposition on AISI-304, submitted for publication in Oxidation of Metals.

[23. H.C. Stumpf, A.S. Russell, J.W. Newsome and C.M. Tucker Ind. Eng. Chem. 42 (1950) 1398.

[24] R. Goton, PhD Thesis, no. 146. University of Lyon, France, 1955.

[25] J. Bugosh, R.L. Brown, J.R. McWhorther, G.W. Sears and R.J. Sippel, Ind. Eng. Chem. Chem. Prod. Res. Develop., 1(3) (1962) 157.

[26] H. Saalfeld, Neues. Jahrb. Mineral. Abh., 95 (1960) 1. 